\title{
Towards a regional ontology of management education in Africa: A complexity leadership theory perspective
}

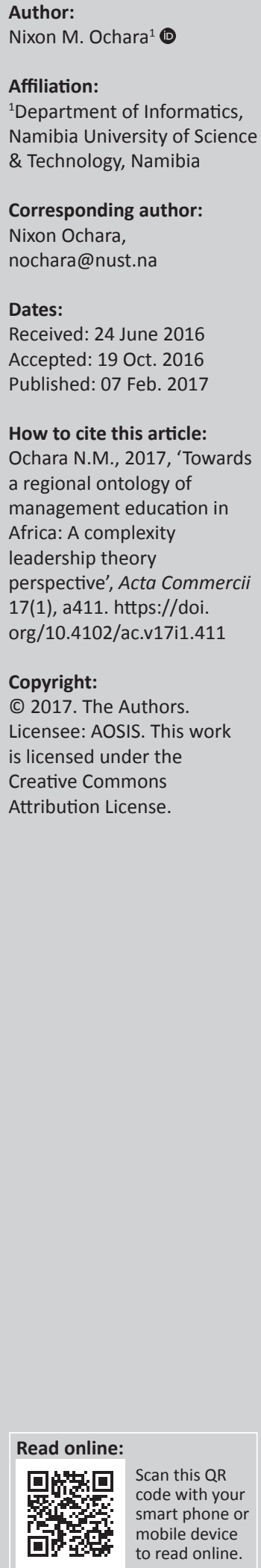

Orientation: The title of this critique, 'Towards a regional ontology of management education in Africa: A complexity leadership theory perspective', sought to capture a paradox in the prescriptive nature and universalistic leaning of current leadership theories; yet local realities may call for being cognisant of (possible extant) regional ontologies.

Motivation for the study: The argumentation and analysis developed in this article were based on a synthesis of ideas from literature to evolve a preliminary regional ontology for reorienting business and management education relevant for Africa.

Research design, approach and method: The critique was structured on insights from complexity leadership theory. The outcome was a proposition for an Afrocentric regional ontology for strengthening business and management education anchored on four themes: ethical and moral engagement, entrepreneurial leadership, Ubuntu and local National Systems of Innovation (NSI).

These emerging ideas were considered to be tentative and should be considered as a foundation to inform further inquiry into how business and management education in Africa can be better interpreted and legitimised in the behavioural sciences.

Practical/managerial implications: From an Afrocentric perspective, conceptualising and maintaining the logic of leadership was considered to be desirable and imperative in evolving a regional ontology of leadership that takes into account local realities. Of course, we recognised that these defining rationalities are not unique to Africa, but that said; a regional perspective that is unique cannot continue to be ignored but should find their place in discourses about leadership in the 21st century.

Contribution/value-add: The synthesis and narrative presented in this paper concisely summarises and provides traction on how to advance business and management education in Africa.

\section{Introduction}

Since the economic meltdown that began in the United States in 2008, there have been numerous and cryptic analyses seeking to pinpoint the underlying causes of the crisis. Some of these attempts have taken an economics perspective, with Kotz (2009) making the argument that the financial and economic crisis that has since become a global phenomenon was the start of a systemic crisis of neoliberal capitalism that can be explained from history. From this perspective, the argument is that the same institutional features of neoliberal capitalism that promoted a series of long economic growth for decades may have been the foundation of long-run trends that have led to a systemic crisis. The hallmarks of neoliberal capitalism include: deregulation to allow free trade and capital mobility; privatisation of state enterprises; limits to discretionary fiscal policy; reduction in social spending; anti-trade unionism; reliance on temporary and part time staff; unrestrained, cutthroat competition; and the introduction of market principles inside large corporations (McDonough, Reich \& Kotz 2009). These principles of neoliberal capitalism have formed the backbone of disciplines in economics and business.

Another perspective links the cause of the global financial crisis to the nature of training in business and economics schools. For instance, Giacalone and Wargo (2009) hold the view that the toxic teaching of bad management theories, grounded on assumptions of neoliberal capitalism, is the bane of the global financial crisis and the malaise of corporate scandals that are evident throughout the globe. That business schools have, over the years, inculcated bad values that have culminated in the widespread unethical behaviour visible in most corporate boardrooms and public policy formulation. The Chairman, UK Financial Services Authority, put the blame squarely on business schools when he opined that there had been 'a fundamental intellectual failure' 
in business schools prior to the crisis (Currie, Knights \& Starkey 2010). Phillips et al. (2016) do not mince their words when they claim that:

[...] MBA graduates marched out and destroyed the world financial system. Few in academe have stepped up to take responsibility. We have yet to hear a professor say, 'I taught those people, and I'm sorry. Reports in Forbes, Chronicle of Higher Education, Harvard Business Review and others reveal simultaneous intellectual crises in the disciplines taught in b-schools. (p. 1)

Therefore, as we make claims in this paper, there is widespread recognition that there is a crisis in business- and economicsoriented disciplines (DeLong 2011; Denning 2012; Galbraith 2010; Krugman 2011; Shea 2011). The situation in developing countries is no different, and from a critical perspective this paper takes the view that African countries, as innovation adopters, have been the recipients of business education curricula and influence from the developed countries because of a long history of colonialism. Since the close of the 20th century, the core elements of imperialism related to cultural, social and economic dominance continue to impact every aspect of human life in different parts of the globe (Taylor 2009). The legacy of the continued imperial dominance has resulted in persistent and unequal distribution of technological, political and economic power. As a number of authors eloquently argue, current 'new colonialism' is more visible in economic and political ideologies, propagated more by Western-centric technocrats and entrepreneurs (Blunt \& Jones 1997; Tully 2000). Developing countries, particularly those based in Africa, have grappled with the response and awareness to the vagaries of colonial imperialism for centuries.

There has, over the years, been mounting reluctance to conform to ideals seen to be 'born' in Western countries and imported to Africa without reflection on their relevance to context. The dominant view is that the Western ideals that have received much attention from developing countries have been at the macro-level related to the nature of governance (Ayers 2009), particularly systems of political and social control, human rights and sustainable development (Blunt 1995). However, there is a forceful argument that a core element of Western 'new' imperialism is not confined to macro-governance but also has parallels at the micro-levels. For example, Hofstede (1993) makes the point that the concept of management, as presently used, is an American invention whose idiosyncrasies are not necessarily shared elsewhere. The author highlights three such idiosyncrasies, that is, a focus on market processes, the individual, and on the importance of managers rather than workers. The author further makes a plea for an internationalisation of business and management theories as a way of enriching disciplines related to management and leadership.

The hegemony of Western imperialism on management and leadership disciplines has not received as much resistance from developing countries as is the case with questions related to macro-level governance. There are persuasive arguments that at the micro-domains of management and leadership application, there is still an allure to replicate Western theory and practice (Kiggundu 1989). Such attraction to Western management and leadership thought at the micro-domain has been attributed to the perceived minimal impact and visibility that micro systems of organisations and management have on the well-being of nations (Blunt \& Jones 1997; Bolden \& Kirk 2009). The contribution of this paper is linked to the growing recognition that management and leadership of both public and private organisations are increasingly being recognised as central to national development; therefore, the prescriptiveness and the idiosyncrasies of Western thinking cannot be applied uncritically to developing countries. The purpose of this paper is to urge continuing debate on the wisdom of uncritically adopting and replicating Western perspectives in management education in the developing countries of Africa, with a view to evolving a 'regional' ontology that takes cognisance of the unique contexts of Africa. We begin to contribute to the debate in the form of an explanatory critique, by advocating for a regional ontology for management and leadership education for Africa.

\section{Complexity leadership theory as an analytical framework}

The title of this critique, 'Towards a regional ontology of management education in Africa: A complexity leadership theory perspective', seeks to capture a paradox in the prescriptive nature and universalistic leaning of current management and leadership theories; yet local realities may call for being cognisant of (possible extant) regional ontologies. Part of the attraction to offer a critique of a theory in the leadership field is the fact that it remains 'curiously unformed' (Hackman \& Wageman 2007:43); while Warren Bennis as early as 1959 , stated that ' $[. .$.$] probably more has been written$ and less is known about leadership than any other topic in the behavioural sciences' (Bennis 1959:260). We wade through this 'curiously unformed' field, to add a particular voice: an Afrocentric voice which is rarely heard in a fiercely behavioural school that claims ownership of the field, yet there maybe indications that, as globalisation gains pace, the scales should be tipping towards reifying a more integrative view of leadership that elevates regional ontologies. The choice of the concept of leadership is deliberate: that one does not manage people as is predominantly assumed in management theory and practice, but that one leads people (Drucker 1998). Thus we focus on leadership, a key element of organisational science, the focus of business education throughout the world.

Specifically, the critique is grounded on complexity leadership theory (CLT), a contemporary view of leadership which is based on dynamic capabilities of complex adaptive systems $(\mathrm{CAS})^{1}$ and focuses on the strategies and behaviours that 'foster organizational and subunit creativity, learning, and

1.Changeable structures with multiple, overlapping hierarchies that are linked with one another in a dynamic, interactive network. They are structures that are capable one another in a dynamic, interactive network. They are structures that are capable
of creative problem-solving, learn and adapt quickly, and emerge naturally in social systems (Uhl-Bien, Marion \& McKelvey 2007:3). 
adaptability that emerge when the right CAS dynamics are activated' (Uhl-Bien et al. 2007:3). As a contemporary view of leadership, CLT moves beyond views of leadership rooted in top-down bureaucratic models that assume stable, production-oriented economies, towards less stable, knowledge-oriented economies that describe the current society (Uhl-Bien et al. 2007). We see CLT as a key theory of leadership, that is, current and adaptive, based on a number of assumptions (which from a regional perspective, enable us to pose a number of 'big' questions as the object of this critique (Table 1).

We approach these questions as follows. We demonstrate, through critique, how the rendering of leadership as a social construction precludes Afrocentric constructions that can contribute to advancing business and management education in Africa. The key role played by dominant language groups is explored. We then examine how a focus on the process of leadership in CLT reinforces Western-type management philosophies in business and management education; while a focus on informal dynamics may be conflictual to how formal organisations are run. We also question the universalistic assumption that we are in a knowledge-based society, which assumes that the focus of management problems are no longer technical, yet many societies in Africa are still grappling with industrial age challenges. Lastly, we offer an alternative conceptualisation of CLT that is relevant to the realities of Africa, that is, a regional ontology of management education for Africa.

We employ the use of the term 'regional ontology', derived from Martin Heidegger (in the manner used by Sewchurran, Smith \& Roode 2010), to refer to 'as lived' practices and experiences of a particular social group. The idea of regional ontology can also be explained from Bourdieu's 'theory of practice', which seeks to understand and explain actions of individuals and social groups, formed by their cultures, traditions and objective structures within a particular society (Rhynas 2005). Therefore, we recourse to the concept of regional ontology as a metaphor that can aid in mapping the 'as lived' experience and practice of leadership in Africa Africa as a social group, which is geographically distinct and socially categorised as a developing region. We also focus on Africa, given that it has been identified as the 'Other', whose 'voice' is silent in discourses concerning management and leadership. A focus on explaining other practices from a regional ontology perspective is not unique to this contribution (see Sewchurran et al. 2010); but there have been propositions that are specifically relevant to giving priority to the regional ontology of leadership contexts found in literature (see Sydow et al. 2011).

\section{Research approach}

This is a conceptual paper, guided by a critical research perspective in line with Bourdieu's theory of practice, which emphasises the asymmetric distribution of symbolic and social assets in society, which cause and reproduce discriminatory social stratification such as between developed and developing countries (Myers \& Klein 2011). Bourdieu (1990) explicates symbolic and social assets or capital into four categories: economic capital, social capital, cultural and symbolic capital. These forms of capital can be used to produce, reproduce or maintain inequality or domination (Bourdieu 1977). Bourdieu gives an example of his research in higher education in France. He found that working class children continue to be seriously underrepresented in higher institutions of learning even though education in universities in France is open to all. He linked the under-representation of working class children in French universities to a lack of cultural capital related to knowledge of music, contemporary literature and art. Bourdieu's theory of practice resonates with our emancipatory quest: to understand and explain the nature of Western domination in management and leadership education in Africa and provide an alternative conceptualisation. Therefore, this paper is underpinned ontologically from a critical research perspective (Table 2), specifically in the lineage of Bourdieu's theory of practice.

From an epistemological perspective, a subjectivist and reflexive approach is adopted in the conceptual claims made in this paper. The methodology of relevance in this paper recognises the primacy of dialog; and its role in transformation as a form of emancipation. The argument

TABLE 2: Critical theory paradigm.

\begin{tabular}{ll}
\hline Ontology & Critical research \\
\hline Epistemology & Subjectivist, reflexivity \\
Methodology & Dialogic, transformative \\
Methods & Reflexive critique; theoretical thematic analysis \\
Discursive practices & $\begin{array}{l}\text { Context, informal dynamics, process of leadership; } \\
\text { knowledge society }\end{array}$ \\
\hline
\end{tabular}

Source: Adapted from Guba 1990

TABLE 1: Complexity leadership theory(CLT) assumptions. CLT assumptions
Leadership is socially constructed in and from a context consisting of interactions and
interdependencies among agents (people, ideas), hierarchical divisions, organisations and environments.

CLT focuses on the concept and process of leadership.

CLT focuses on adaptive leadership, which occurs in emergent, informal dynamics throughout the organisation rather than on formal administrative leadership.

Leadership in the Knowledge Era occurs in the face of adaptive challenges rather than technical problems, which are more characteristic of the Industrial Age.

Source: Adapted from Uhl-Bien et al. 2007

\section{'Big' questions}

How does language play a role in reinforcing 'true' accounts of contexts that influence leadership action?

How does the rendering of leadership as a social construction preclude Afrocentric constructions that can contribute to advancing business and management education in Africa?

To what extent does a focus on the process of leadership advance Western-oriented management philosophies?

How does this view conflict with established bureaucracies that have existed for long periods of time?

To what extent is a focus on informal dynamics counter to the formal organisation?

Where does this leave Africa, which, still grapples with extractive industries reminiscent of the industrial era? 
is that, apart from seeking to expose the misaligned and unsustainable dominant Western pedagogy in the teaching and delivery of management and leadership education in Africa, this contribution seeks to start a dialogue that can culminate in a consensus: an African philosophy of management and leadership education. This dialogue, as a conceptual contribution, is a form of reasoning that human beings use to seek understanding and consensus. Therefore, in our quest to enhance and make relevant the teaching of management and leadership education in Africa, we seek consensus as a form of Habermas's 'ideal speech situation', 'where all assertions are equally open to critical scrutiny' (Kemmis 2001:93).

In diagnosing the problem, the researcher's experiences as a business school student (1992-2009) and as a scholar and director of a school of business (2003-2016); allowed for a more reflexive critique to be adopted. The principle of reflective critique ensures people reflect on issues and processes and make explicit their interpretations, biases, assumptions and concerns upon which judgments are made (O'Brien 1998). The three key aspects of such an approach takes into account that, firstly, social reality is consensually validated through language; secondly, that each person's ideas are equally significant as potential resources for creating interpretive categories of analysis; and finally, that the change process potentially threatens all previously established ways of doing things, thus creating psychic fears among the practitioners. We use this approach by employing a theoretical thematic analysis of literature. Theoretical thematic analysis is driven by the researcher's theoretical or analytic interest in the area, and is thus more explicitly analyst-driven (Braun, Clarke \& Terry 2014), and in this case, was based on complexity leadership theoretical lens.

\section{Reflexive critique from a complexity leadership theory perspective}

Our theoretical interest revolved around the use of complexity leadership theory and its concepts to guide the conceptual development of this paper. The key concepts that were employed were language and context, informal dynamics, process of leadership and knowledge society.

\section{Language and the social construction of context in leadership action}

CLT, in its problematisation of leadership, considers it as a social construction which goes beyond personal leadership view to include, among others, the work setting and/or context (Zaccaro \& Horn 2003). For instance, the analysis by Avolio, Walumbwa and Weber shows that leadership is no longer simply described as an individual characteristic or difference but rather is depicted in various models as dyadic, shared, relational, strategic, global and a complex social dynamic (Avolio, Walumbwa \& Weber 2009). This latter focus on leadership draws our attention to three main constructs that anchor CLT's view of the nature of leadership: organisational context of leadership; complexity in the global environment and leadership as a strategic imperative. The Organisational Context of leadership frames leadership as an 'influence process - and its resultant outcomes (goal achievement)', a key component of the strategic imperative. In this critique, we advance the notion that as leadership is viewed as a social construction, its framing as an 'influence process' is mediated by language, as a tool for propagating shared and collective meanings.

Grint (2005) advances the proactive role of leadership in the construction of context using language and that the critical elements are what counts as 'true', 'objective' and 'fact', which are the result of contending accounts of 'reality' using language. The implication is that the prevailing account of leadership theory relevant for business and management is often mediated by dominant language groups. For instance in the field of strategy, Mantere (2013) considers the use of language by linguistic experts (institutional gatekeepers, authors of strategy texts, practitioners and teachers) to advance accepted beliefs, practices and labels (e.g. terminologies used in a discipline) used in interpretation and legitimisation of the business and management discipline (field level). At least 26 African countries list English as the official language of communication, while there is also an increasing number of other African countries such as Ethiopia that seek to develop and implement consistent and effective English language teaching policies, and the need for quality English teaching materials for African classrooms (Plonski, Teferra \& Brady 2013). Such dominance of English, as a language for propagating management education, implicit in the assumptions of CLT, continues to reinforce Western models and approaches which do not take into account African realities. Therefore, to evolve an African philosophy of leadership and management, African linguistic experts (in terms of discipline institutional gatekeepers, authors of management texts, practitioners and teachers) must respond to the call by Fink et al. (2005) for the need to reify African languages in management education as part of the Ubuntu concept.

\section{Reinforcing Western management thought: A processual approach}

More than two decades ago, Hosking reiterated the imperative of focusing on leadership as that which requires understanding its processes as influential 'acts of organising' interactions (relationships, activities, and sentiments), interdependencies and social order (Hosking 1988). This is one of the key notions of CLT. These influential 'acts of organising' are rarely attributable to a single individual, but possibly to distributed persons, teams, organisational units and societal units. In other words, leadership as an influence process is realistically an 'attributed influence' (Gronn 2002:429) which is not linked to a single individual but to various organisational members acting within a particular context. From the perspective of strategy-as-a-languagegame propagated by Mantere (2013), while linguistic experts at the discipline level define an orthodoxy for a discipline, at the network level, relationships, interactions and 
interdependencies are rule-governed (by the dominant languages); while at the organisational level, accepted terminologies are sanctioned by owners of the management practices. From a process perspective, leadership is thus seen as a network of actions, through distributed influence, that are still influenced or evolved from dominant language networks (English, German, French, etc.) from the Western world. These language networks have family resemblances and act to enforce 'rules-of-practice' in management practice as well as sanction the use of management labels that continue to influence management education in Africa. In part, these language networks have achieved this partly through colonialism and much more recently through neocolonialism as the article by Plonski et al. (2013) attest to.

To move beyond the Western dominated 'family resemblances' that continue to devalue the contribution of African management thought, Dobra (2012) asserts that there is a 'nascent African individual who deploys strategies to mobilise material and symbolic power in order to act as an agent of change within the public sphere'. Thus the emergence of a civil society of individuals is correlated to a type of state that constitutes the individual as responsible (Dobra 2012:74). In seeking an alternative conceptualisation of an African management philosophy, we will adopt an analytical lens of the individual as a 'responsible' citizen as well as consider the institutional structures within which the individuals function. We see this as an appropriate lens to understand the nature of leadership in context; as defined institutional structures that influences individual action. African Individuals as active citizens involved in agency, which may call for Afrocentric view involving the writing of the African historiography as a basis of a leadership paradigm that takes into account African realities.

\section{Informal dynamics and the knowledge society as organising lenses}

Two other notions underscored by CLT are: a focus on adaptive leadership, which occurs in emergent informal dynamics throughout the organisation rather than on formal administrative leadership; and that leadership in the Knowledge Era occurs in the face of adaptive challenges rather than technical problems, which are more characteristic of the Industrial Age (Uhl-Bien et al. 2007). The first critique is related to the use of informal dynamics in CLT. While adaptive leadership as a metaphor is attractive in understanding management in complex environments, the notion of informal dynamics presumes a formal administrative structure that is functioning efficiently and effectively, especially in large bureaucracies. Informal dynamics, as adaptive dynamics that continually respond to rapid changes in the environment (Hazy 2011), are useful in augmenting the formal administrative structure, but on their own, may not be effective in large and complex organisations in which a functioning bureaucracy may be a prerequisite.

Therefore, African scholars blindly adopting the terminology of informal dynamics without recognising that formal bureaucracy has been part and parcel of Western management thought and practice for over 100 years, may result in still further reinforcing realities that may not adequately capture African realities. African bureaucracies, and therefore their administrative structures, are still nascent (given a colonial history of barely 60 years). Given that bureaucracy (and its formal structure of administrative control) implies a larger organisational and normative structure where rationality and control are critical attributes, the technical and procedural rationality of bureaucracy still requires reification in African realities rather than the notion that bureaucratic organisation should be replaced (but can be augmented) by other structural forms such as networks forms and cooperative and powersharing forms (Olsen 2008). Thus, the use and application of informal dynamics as a metaphor can only be used to augment the continuing institutionalisation and development of strong bureaucracies in developing countries of Africa.

The second metaphor that may continue to inappropriately propagate Western management thought and education, while masking African realities, is the elevation of the concept of knowledge society in CLT, with the assumption that industrial era type technical problems are no longer relevant. While we recognise significant industrial output from Africa from 1950 to 1990, with higher per capita manufacturing growth rates (Bénétrix, O'Rourke \& Williamson 2015), a majority of African countries are still grappling with industrialera-type technical problems. Thus focusing management education that has 'leaped' towards emphasising more knowledge-based perspectives is unlikely to capture the realities of most African countries that are seeking to industrialise. Of course, Africa is part and parcel of the knowledge economy, especially taking into account the growth of advanced Information and Communication Technologies (ICTs), but our take is that industrial age technical problems still remain a forte of African management education. Thus, while CLT focuses attention on knowledge-based type problems, we should remain cognisant of development realities of Africa, and thus African scholars' interpretation activities of management problems should take into account the relevant realities for Africa.

\section{Towards a regional ontology for management education for Africa}

In this section, we seek to provide an extension to CLT that takes into account an Afrocentric perspective. Grint and Jackson (2010) opine that 'providing a critique without an alternative is not a position of moral supremacy but moral illiteracy' (p. 349). Therefore, we do not just provide a critique for the sake of critiquing but seek to provide an alternative thinking that builds on the critique and takes into account regional realities. The anchors for the improved and/or alternative thinking to CLT is presented in Table 2 and revolve around the following themes: the need to exercise Ethical and Moral Leadership; Entrepreneurial Leadership; Institutionalisation of Leadership Practices and a National System of Innovation to provide a systemic view (Ochara 2013). 
The first anchor is based on the concept of moral engagement a la Bandura, which requires accepting responsibility for one's behaviour (Naidoo 2013). In Naidoo's analysis of an e-government project in South Africa, he accentuates the pervasiveness of collective moral disengagement in decisionmaking by public managers. In like manner, we view business and management scholars in Africa to be collectively, morally disengaged; thus, the need to intentionally focus collectively (for instance through regional networks) to evolve an African philosophy of management. Collectively, there is need to consider more systematic and collective moral engagement strategies, as a basis of ensuring and cementing an African voice in the organisational sciences in the global arena. This approach finds support in literature (see Elnaghi, Alshawi \& Missi 2007; Marche \& McNiven 2003; OECD 2003). Adopting moral engagement strategies (What) will allow participants to reflect deeply on how, where, who, when and why adopting an Afrocentric view to management education can enhance the African voice in the behavioural school (Table 3).

In effect, ethical and moral engagement (What) of various stakeholders is likely to ensure the social sustainability of various legitimisation and mobilisation activities of an Afrocentric model of management education. This requires that ethical and moral leadership practices orientated towards an Afrocentric view should take into account not only various levels of participation (Where) but also who are the stakeholders (Who). Of course development and institutionalising of ethical and moral leadership engagement is a long-term process and is more continuous and evolutionary (When) and needs to take into account that the overall rationale for engagement in such practices is to ensure the social sustainability (Why) of the modes of business and management education adopted in Africa. Realising ethical and moral leadership engagement is also linked to challenges related to capacity.

The second locus of the regional ontology of management education relevant for CLT in Africa is anchored on the fact that entrepreneurial leadership can provide socio-economic justification (Why) for the increasing levels of investments in various sectors, a forte of management logic throughout the world. For Africa, and given the fact that many African countries are still trying to industrialise, a focus on technology innovation and entrepreneurship (what) is likely to move the continent from the industrial towards a knowledge-based economy. Africa continues to face daunting challenges, which sometimes appear insurmountable to outside observers, yet the current crop of entrepreneurs (Who) from Africa are starting and maintaining enterprises that are providing solutions to these challenges. Thus, a curriculum that anchors business and management education on innovation and entrepreneurship is likely to move the continent towards a much more knowledge-based economy, as a region.

The third locus of the proposed regional ontology, dubbed African management and leadership institutionalisation, recognises the need to emphatically define and strongly anchor the African philosophy of Ubuntu (what) in business and management education in Africa. It is recognised that the current orientation to how business and management education is taught is partly related to a colonial legacy and historicity of African states (Hagmann \& Péclard 2010); ineffectiveness of Western aid (Scott 1998); more perilous and risky political environments (Goldsmith 2007); and leadership based on foreign values (Jennings 2007); etc. Thus, to attain effective and appropriate leadership success in Africa, Jennings (2007) recommends strengthening and institutionalising leadership by incorporating African values, while taking into consideration beneficial aspects of Western civilisation (What). We concur, and hopefully this strengthening and incorporation of African values in business and management curricula will improve bureaucratic quality in administrative matters as well as make the exercise of leadership relevant in the context of Africa.

The final locus of the proposed regional ontology of orientating business and management education to be Afrocentric is to incorporate the role of local national systems of innovation (NSI), and how such systems can effectively impact the visibility of Africa on a global scale. Most systems of innovation recognised in policy documents in various African countries are woefully misaligned to the knowledgebased economies of today, in which the smooth operation of innovation systems depends on the fluidity of knowledge flows - among enterprises, universities and research institutions (Who). This requires developing leadership capabilities that respect the contribution of systems of innovation in making societies better, as has happened with

TABLE 3: African regional ontology of leadership.

\begin{tabular}{|c|c|c|c|c|}
\hline \multirow[t]{2}{*}{ ASPECTS } & \multicolumn{4}{|c|}{ LOCUS } \\
\hline & Ethical and Moral Leadership & Entrepreneurial Leadership & $\begin{array}{l}\text { African Management and Leadership } \\
\text { Institutionalisation }\end{array}$ & National System of Innovation \\
\hline What & $\begin{array}{l}\text { Ethical and moral } \\
\text { engagement }\end{array}$ & $\begin{array}{l}\text { Technology innovation and } \\
\text { entrepreneurship }\end{array}$ & $\begin{array}{l}\text { African values (Ubuntu); aspects of } \\
\text { Western civilisation }\end{array}$ & $\begin{array}{l}\text { Research and development of 'local' } \\
\text { knowledge systems }\end{array}$ \\
\hline How & $\begin{array}{l}\text { Book publications, conferences, African } \\
\text { management curricula, local language } \\
\text { adaptations }\end{array}$ & $\begin{array}{l}\text { Revamping business schools curricula; } \\
\text { service-based learning }\end{array}$ & $\begin{array}{l}\text { Mainstreaming formal and informal } \\
\text { organising forms in Africa }\end{array}$ & $\begin{array}{l}\text { Research and development; } \\
\text { education }\end{array}$ \\
\hline Where & $\begin{array}{l}\text { Schools, universities, local } \\
\text { practices }\end{array}$ & $\begin{array}{l}\text { Business schools, business } \\
\text { owners }\end{array}$ & $\begin{array}{l}\text { Formal and informal organising } \\
\text { structures }\end{array}$ & $\begin{array}{l}\text { Universities; research and development } \\
\text { centres; leadership centres }\end{array}$ \\
\hline Who & $\begin{array}{l}\text { National and local government/business } \\
\text { leaders; scholars, individuals }\end{array}$ & $\begin{array}{l}\text { Individuals, universities and } \\
\text { communities }\end{array}$ & $\begin{array}{l}\text { National, regional, local structures and } \\
\text { individuals }\end{array}$ & $\begin{array}{l}\text { National, business, educational and civil } \\
\text { society leadership; universities }\end{array}$ \\
\hline When & Continuous and evolutionary & Transformative and disruptive & Continuous and evolving & Disruptive and continuous \\
\hline Why & Social sustainability & Socio-economic rationality & Legal and professional rationality & Global focus on knowledge flows \\
\hline
\end{tabular}

Source: Adapted from Ochara 2013 
countries such as Thailand, South Korea and China, which 60 or so years ago, were at the same developmental phase as a number of countries in Africa. We are not touting NSI as a panacea, but it is part of the 'puzzle' that can aid in the process of strengthening leadership and management education in Africa.

\section{Conclusion}

The argumentation and analysis developed in this article provide a synthesis of ideas from a review of literature to evolve a preliminary regional ontology for re-orienting business and management education to be relevant for Africa. By critiquing and building on the foundations of CLT, the article recommends an Afrocentric regional ontology for strengthening business and management education anchored on four themes: ethical and moral engagement, entrepreneurial leadership, Ubuntu and local Nations Systems of Innovation (NSI). These ideas are tentative and can preliminarily be considered as a foundation to inform further inquiry into how business and management education in African can be better interpreted and legitimised in the behavioural sciences.

From an Afrocentric perspective, conceptualising and maintaining the logic of leadership is not only desirable but also imperative to evolve a regional ontology of leadership that takes into account the Afrocentric realities. Of course we recognise that these defining rationalities (Table 3) are not unique to Africa, but that said, a regional perspective that is unique to Africa cannot continue to be ignored but should find their place in discourses about leadership in the 21st century. The synthesis and narrative presented in this paper concisely summarises and provides traction on how to advance business and management education in Africa.

\section{Acknowledgements}

\section{Competing interests}

The authors declare that they have no financial or personal relationships which may have inappropriately influenced them in writing this article.

\section{References}

Avolio, B.J., Walumbwa, F.O. \& Weber, T.J., 2009, 'Leadership: Current theories, research, and future directions', Annual Review of Psychology 60, 421-449. http://dx.doi.org/10.1146/annurev.psych.60.110707.163621

Ayers, A.J., 2009, 'Imperial liberties: Democratisation and governance in the new imperialorder', PoliticalStudies 57(1), 1-27.http://dx.doi.org/10.1111/j.1467-9248. 2008.00723.x

Bénétrix, A.S., O'Rourke, K.H. \& Williamson, J.G., 2015, 'The spread of manufacturing to the poor periphery 1870-2007', Open Economies Review 26(1), 1-37. http:// dx.doi.org/10.1007/s11079-014-9324-x

Bennis, W.G., 1959, 'Leadership theory and administrative behavior: The problem of authority', Administrative Science Quarterly 4, 259-301. http://dx.doi.org/10. 2307/2390911

Blunt, P., 1995, “Cultural relativism, "good" governance and sustainable human development', Public Administration and Development 15(1), 1-9. http://dx.doi. org/10.1002/pad.4230150102

Blunt, P. \& Jones, M.L., 1997, 'Exploring the limits of Western leadership theory in East Asia and Africa', Personnel Review 26(1/2), 6-23. http://dx.doi.org/10.1108/ 00483489710157760

Bolden, R. \& Kirk, P., 2009, 'African leadership surfacing new understandings through leadership development', International Journal of Cross Cultural Management 9(1), 69-86. http://dx.doi.org/10.1177/1470595808101156
Bourdieu, P., 1977, Outline of a theory of practice, vol. 16, Cambridge University Press, Cambridge.

Bourdieu, P., 1990, The logic of practice, Stanford University Press, Stanford, CA.

Braun, V., Clarke, V. \& Terry, G., 2014, 'Thematic analysis', Qualitative Research in Clinic and Health Psychology, 95-114.

Currie, G., Knights, D. \& Starkey, K., 2010, 'Introduction: A post-crisis critical reflection on business schools', British Journal of Management 21(Suppl 1), s1-s5. http:// dx.doi.org/10.1111/j.1467-8551.2009.00677.x

DeLong, J.B., 2011, 'Economics in crisis', The Economists' Voice 8(2). http://dx.doi. org/10.2202/1553-3832.1854

Denning, S., 2012, 'How Agile can transform manufacturing: The case of Wikispeed', Strategy \& Leadership 40(6), 22-28. http://dx.doi.org/10.1108/10878571211278859

Dobra, A., 2012, 'The democratic impact of ICT in Africa', Africa Spectrum 47, 73-88.

Drucker, P.F., 1998, Peter Drucker on the profession of management, Harvard Business Press, Boston, MA.

Elnaghi, M., Alshawi, S., \& Missi, F., 2007, 'A Leadership Model for e-Government Transformation' Proceedings of European and Mediterranean Conference on Information Systems 2007, Polytechnic University of Valencia, Spain, 1-12.

Fink, G., Holden, N., Karsten, L. \& Illa, H., 2005, 'Ubuntu as a key African management concept: Contextual background and practical insights for knowledge application' Journal of Managerial Psychology 20(7), 607-620. http://dx.doi.org/10.1108/ 02683940510623416

Galbraith, J.K., 2010, "Why the "experts" failed to see how financial fraud collapsed the economy', Written Statement to Members of the Senate Judiciary Committee, viewed 10 August 2016, from http://www.alternet.org/story/146883/james_k. galbraith\%3A_why_the_\%27experts $\% 27$ failed_to_see_how_financial_fraud_ collapsed_the_economy

Giacalone, R.A. \& Wargo, D.T., 2009, 'The roots of the global financial crisis are in our business schools', Journal of Business Ethics Education 6, 147-168.

Goldsmith, A.A., 2007, 'Is governance reform a catalyst for development?', Governance 20(2), 165-186. http://dx.doi.org/10.1111/j.1468-0491.2007.00352.x

Grint, K., 2005, The sociology of work: Introduction, Polity, Cambridge.

Grint, K. \& Jackson, B., 2010, 'Toward "socially constructive" social constructions of leadership', Management Communication Quarterly 24(2), 348-355. http:// dx.doi.org/10.1177/0893318909359086

Gronn, P., 2002, 'Distributed leadership as a unit of analysis', The Leadership Quarterly 13(4), 423-451. http://dx.doi.org/10.1016/S1048-9843(02)00120-0

Guba, E.G., (ed.), 1990, The paradigm dialog, Sage, Newbury Park, CA.

Hackman, J.R. \& Wageman, R., 2007, 'Asking the right questions about leadership: Discussion and conclusions', American Psychologist 62(1), 43-47. http://dx.doi. org/10.1037/0003-066X.62.1.43

Hagmann, T. \& Péclard, D., 2010, 'Negotiating statehood: Dynamics of power and domination in Africa', Development and Change 41(4), 539-562. http://dx.doi. domination in Africa', Development and
$\mathrm{org} / 10.1111 / \mathrm{j} .1467-7660.2010 .01656 . x$

Hazy, J.K., 2011, 'Leadership as process: A theory of formal and informal organizing in complex adaptive systems', Unpublished Paper, 31 December.

Hofstede, G., 1993, 'Cultural constraints in management theories', The Academy of Management Executive 7(1), 81-94. http://dx.doi.org/10.5465/ame.1993. 9409142061

Hosking, D.M., 1988, 'Organizing, leadership and skilful process [1]', Journal of ManagementStudies25(2),147-166.http://dx.doi.org/10.1111/j.1467-6486.1988. tb00029.x

Jennings, Y., 2007, 'Building on the values of the past as a foundation for sustainable leadership in African countries', Conflict Trends 2, 38-43.

Kemmis, S., 2001, 'Exploring the relevance of critical theory for action research: Emancipatory action research in the footsteps of Jurgen Habermas', in P. Reason \& H. Bradbury (eds.), Handbook of action research: Participative inquiry and $\&$ H. Bradbury (eds.), Handbook of action resear
practice, pp. 91-102, Sage, Thousand Oaks, CA.

Kiggundu, M.N., (1989). Managing organizations in developing countries, Kumarian Press, West Harford, CT.

Kotz, D.M., 2009, 'The financial and economic crisis of 2008: A systemic crisis of neoliberal capitalism', Review of Radical Political Economics 41(3), 305-317. http://dx.doi.org/10.1177/0486613409335093

Krugman, P., 2011, 'The new economic geography, now middle-aged', Regional Studies 45(1), 1-7. http://dx.doi.org/10.1080/00343404.2011.537127

Mantere, S., 2013, 'What is organizational strategy? A language-based view', Journal of Management Studies 50(8), 1408-1426. http://dx.doi.org/10.1111/joms.12048

Marche, S. \& McNiven, J.D., 2003, 'E-government and e-governance: The future isn't what it used to be', Canadian Journal of Administrative Sciences/Revue Canadienne Des Sciences de l'Administration 20(1), 74-86.

McDonough, T., Reich, M. \& Kotz, D.M., 2009, Understanding contemporary capitalism: Social structure of accumulation theory for the twenty first century, Cambridge University Press, Cambridge.

Myers, M.D. \& Klein, H.K., 2011, 'A set of principles for conducting critical research in information systems', Mis Quarterly 35(1), 17-36.

Naidoo, R., 2013, 'Toll roads: Analysing a case of collective moral disengagement in an e-government project: Challenges in leadership of ICT policy and e-development', African Journal of Information and Communication: Leadership in the Electronic Age: A Broad Inter-disciplinary Practice 13, 108-122.

O'Brien, R., 1998, An overview of the methodological approach of action research, Faculty of Information Studies, University of Toronto, Toronto. 
Ochara, N.M., 2013, 'Leadership for the electronic age: Towards a developmentoriented, socio-technical ontology of leadership: Scene setting', African Journal of Information and Communication: Leadership in the Electronic Age: A Broad InterInformation and Communication
disciplinary Practice 13, 1-12.

OECD, 2003, Checklist for e-Government leaders, viewed 29 October 2013, from http://www.oecd.org/dataoecd/62/58/11923037.pdf

Olsen, J.P., 2008, 'The ups and downs of bureaucratic organization', Annual Review of Political Science 11, 13-37. http://dx.doi.org/10.1146/annurev.polisci.11.060106. 101806

Phillips, F., Hsieh, C.H., Ingene, C. \& Golden, L., 2016, 'Business schools in crisis', Journal of Open Innovation: Technology, Market, and Complexity 2(1), 10. http:// dx.doi.org/10.1186/s40852-016-0037-9

Plonski, P., Teferra, A. \& Brady, R., 2013, 'Why are more African countries adopting English as an official language', in Presented at African Studies Association Annual Conference, Baltimore, MA, 23 November.

Rhynas, S.J., 2005, 'Bourdieu's theory of practice and its potential in nursing research', Journal of Advanced Nursing 50(2), 179-186. http://dx.doi.org/10.1111/j.1365 2648.2005.03377.x

Scott, G., 1998, 'Who has failed Africa? IMF measures or the African leadership?' Journal of Asian and African Studies 33(3), 265-274. http://dx.doi.org/10. 1177/002190969803300303
1
Sewchurran, K., Smith, D. \& Roode, D., 2010, 'Toward a regional ontology for information systems project management', International Journal of Managing Projects in Business 3(4),681-692. http://dx.doi.org/10.1108/ Managing Projects in
17538371011076118

Shea, C., 2011, 'Fraud scandal fuels debate over practices of social psychology', Chronicle of Higher Education, viewed 10 August 2016, from http://chronicle. com/article/As-Dutch-Research-Scandal/129746

Sydow, J., Lerch, F., Huxham, C. \& Hibbert, P., 2011, 'A silent cry for leadership: Organizing for leading (in) clusters', The Leadership Quarterly 22(2), 328-343. http://dx.doi.org/10.1016/j.leaqua.2011.02.008

Taylor, I., 2009, 'The South will rise again? New alliances and global governance: The India - Brazil - South Africa Dialogue Forum', Politikon 36(1), 45-58. http://dx.doi. org/10.1080/02589340903155393

Tully, M., 2000, No full stops in India, Penguin, London, UK.

Uhl-Bien, M., Marion, R. \& McKelvey, B., 2007, 'Complexity leadership theory: Shifting leadership from the industrial age to the knowledge era', The Leadership Quarterly 18(4), 298-318. http://dx.doi.org/10.1016/j.leaqua.2007.04.002

Zaccaro, S.J. \& Horn, Z.N.J., 2003, 'Leadership theory and practice: Fostering an effective symbiosis', The Leadership Quarterly 14(6), 769-806. http://dx.doi. org/10.1016/j.leaqua.2003.09.009 